Jurnal Pakarena

Volume 4 Nomor 1, Juni 2019

e-ISSN: 2550-102X dan p-ISSN: 1693-3990

This work is licensed under a Creative Commons Attribution

4.0 International License

\title{
Kreativitas Visual Pada Desain Poster Iklan Komersial Karya Mahasiswa
}

\section{Irfan, Jalil, Satriadi}

Keywords :

Visual, Kreativitas, Poster

\section{Corespondensi Author}

Desain Komunikasi Visual, Universitas Negeri Makassar, Fakultas Seni dan Desain Jln. Dg. Tata Kampus UNM

Parangtambung irfanridh@unm.ac.id satriadi@unm.ac.id

\begin{abstract}
ABSTRAK
Kreativitas visual adalah kemampuan memilih dan mengolah visual menarik yang akan digunakan untuk kebutuhan tertentu. Visual merupakan salah satu unsur penting desain grafis, visual memiliki fungsi sebagai penyampai dan penguat pesan dalam iklan, visual dapat berupa gambar manual, hasil foto, ilustrasi gabungan manual dan digital, bahkan dapat berupa rekayasa font. Untuk memahami lebih mendalam bagaimana kreativitas visual dimanfaatkan dalam iklan poster media cetak, maka perlu dilakukan penelitian. Penelitian ini merupakan penelitian deskriptif kualitatif yang menjelaskan tentang penggunaan jenis visual pada desain iklan poster komersial karya mahasiswa Desain Komunikasi Visual yang memprogramkan mata kuliah periklanan 1. Penelitian ini bertujuan untuk mengetahui jenis visual apa saja yang paling dominan digunakan oleh mahasiwa pada iklan poster komersial, dengan demikian dapat ditemukan karakteristik dan tingkat kreativitas visual yang menjadi kecenderungan pada tugas desain iklan poster komersial mahasiswa. Penelitian menggunakan pendekatan estetik dengan analisis data menggunakan sistem interaktif Miles dan Huberman. Hasil penelitian menunjukkan bahwa pada umumnya visual yang digunakan telah memenuhi kaidah estetik dan fungsional sebagai media pemberi informasi, ditinjau dari aspek kreativitas dan kaitannya dengan ajakan berimajinasi bagi pelanggang, visual yang digunakan belum menawarkan kreativitas yang mumpuni, sebab masih membatasi diri pada visual produk saja tanpa melibatkan visual penunjang seperti model yang lebih dapat membangkitkan keinginan karena adanya figur yang dilihat sebagai sebuah testimoni yang menarik.
\end{abstract}


Irfan, Jalil, Satriadi, Kreativitas Visual Pada Desain Poster Iklan Komersial Karya Mahasiswa. Hlm 28-35

\section{Pendahuluan}

Visual atau gambar/foto sebagai salah satu unsur dari desain grafis merupakan salah satu bagian penting desain grafis yang memiliki peran dalam menyampaikan informasi. Pada awalnya, ketika teknik fotografi dan percetakan digital belum berkembang di Indonesia, iklan atau disebut juga reklame, banyak menggunakan gambar/ilustrasi yang dibuat secara manual, namun, dengan semakin berkembangnya teknologi fotografi digital dan percetakan digital, maka berbagai iklan banyak dibuat dari gambar atau visual hasil fotografi. Perkembangan gambar manual menjadi gambar digital yang lebih menawarkan banyak teknik editing semakin rumit dan kompleks, namun demikian pemanfaatan visual dalam berbagai iklan komersial senantiasa memperhatikan aspek fungsionalitas dari gambar sebagai penyampai pesan dan aspek estetika agar dapat menarik untuk dipandang dan dibaca.

Dalam berbagai iklan komersial, baik di media elektronik maupun media cetak senantiasa menjadikan gambar sebagai salah satu elemen grafis yang estetis di samping fungsinya sebagai penyampai pesan. Iklan rokok Sampoerna Mild selalu menggunakan rekayasa gambar yang khas dan berkarakter sebagai visual untuk menyampaikan pesan-pesannya yang abstrak dan imajinatif. Tidak sedikit juga iklan di media cetak menggunakan visual sebagai kekuatan desain untuk menambah daya tarik estetik dari iklannya.

Iklan komersial di media cetak khususnya poster kebanyakan menggunakan gambar sebagai instrument penyampai pesan. Oleh sebab itu, gambar dan huruf akan selalu hadir dalam iklan komersial media cetak seperti majalah dan koran dalam berbagai wujudnya, berbagai jenis, berbagai karakteristik, berbagai ukuran, berbagai fungsi, dan berbagai layoutnya. Visual dan huruf akan hadir sebagai daya tarik estetik selain tagline, judul, slogan, headline, subheadline, maupun bodycopy dari sebuah iklan, bahkan bisa jadi huruf menjadi visual utama dalam sebuah iklan komersial di media cetak. Untuk melihat secara jelas bagaimana kreativitas visual serta keragaman karakteristik dan pemanfaatan visual pada iklan dengan media poster, maka diperlukan penelitian tersendiri. Mahasiswa Desain Komunikasi Visual membutuhkan keterampilan dan kreativitas visual agar dapat diterapkan dalam dunia industri, khususnya industri periklanan maupun desain grafis. Menilai kreativitas visual mahasiswa dapat dilakukan dengan mengamati hasil karya tugas desain poster iklan yang diberikan dalam perkuliahan. Mahasiswa yang memprgramkan mata kuliah periklanan merupakan calon 
desainer yang akan terjun dalam dunia industri, sehingga perlu dibekali kreativitas visual yang baik. Esensi seni dan desain adalah kreativitas, dia lahir dari berbagai ide yang dirangkai secara spesifik untuk memenuhi suatu kebutuhan. Kebutuhan selalu berubah, maka upaya pemenuhan kebutuhan itu pun selalu unik, khas, dan beragam, oleh karenanya seni dan kreativitas hanya tumbuh dan berkembang bila ada keberagaman (Marianto, 2015: 1).

Kepekaan seorang desainer iklan dalam menentukan dan memilih jenis visual untuk desainnya merupakan aspek penting yang perlu ditelusuri proses kreatifnya. Selain itu respon klien pengguna iklan terhadap desain iklannya dan jenis visual yang digunakan seperti apa, apakah dapat mempengaruhi jenis tipografi yang telah dipilih oleh desainernya. Dalam konteks ini, bagaimanakah tingkat kreativitas mahasiswa dalam penentuan dan pemilihan jenis gambar dalam sebuah desain poster iklan komersial?. Untuk mengetahui hal tersebut maka perlu dilakukan penelusuran terhadap karya-karya tugas desain poster iklan komersial mahasiswa sebagai calon desainer.

Dari berbagai pengalaman mengajarkan mata kuliah di Program Studi Pendidikan Seni Rupa maupun Desain Komunikasi Visual, maka sangat penting memahami unsur visual selain tipografi, berbagai jenis visual, serta fungsi dan estetika visual dalam karya-karya desain grafis. Hampir seluruh karya desain grafis menggunakan gambar maupun tipografi sebagai salah satu unsur desain yang penting, sebab disamping sebagai teks yang menyampaikan pesan, juga dapat memberikan daya tarik estetika bagi seluruh khalayak pengguna. Oleh sebab itu, memahami kreativitas dalam unsur visual yang telah diterapkan dalam berbagai media grafis seperti desain poster iklan dapat lebih memperkaya sumber-sumber pengetahuan tentang ilmu visual dalam dunia desain komunikasi visual.

Dengan demikian, penelitian tentang kreativitas visual pada desain iklan poster karya mahasiswa peru dilakukan, dengan harapan dapat lebih memperkaya dan memperdalam pemahaman visual dalam iklan poster. Selain itu, hasil penelitian juga dapat menjadi inspirasi berharga bagi para pengajar pendidikan seni rupa maupun desain komunikasi visual serta seluruh mahasiswa desain komunikasi visual dalam memahami, mengkaji, dan mengaplikasikan ilmu visual dalam berbagai rancangan grafisnya, khususnya dalam bentuk poster.

\section{Metode Penelitian}

Populasi penelitian adalah seluruh Tugas Poster Iklan Komersial yang dibuat 
Irfan, Jalil, Satriadi, Kreativitas Visual Pada Desain Poster Iklan Komersial Karya Mahasiswa. Hlm 28-35

oleh Mahasiswa Desain Komunikasi Visual yang memprogramkan mata kuliah Periklanan pada Semester Ganjil tahun Ajaran 2018, terdiri dari dua kelas. sedangkan sampelnya adalah 40 Desain Iklan Poster Komersial karya mahasiswa. Pemilihan sampel tersebut dengan pertimbangan bahwa setiap kelas cukup terwakili dengan mengambil masingmasing 20 karya desain poster.

Proses analisis data meliputi tiga alur kegiatan sebagai suatu system, yaitu (1) reduksi data, (2) sajian data, dan penarikan kesimpulan/verifikasi (Miles dan Huberman, 1992:24). Ketiga komponen analisis tersebut aktivitasnya dilakukan dalam bentuk interaktif dengan proses pengumpulan data sebagai suatu proses siklus (H.B.Sutopo, 2006:117-120). Mengacu pada rumusan masalah, maka analisis data secara lebih jelas akan diuraikan sesuai bagian-bagiannya. Data karya poster mahasiswa akan di uraikan dengan melihat klasifikasi nilai yang diperoleh, dilengkapi dengan keterangan jenis visual yang digunakan serta karaktersitiknya, setelah itu dilakukan analisis secara umum terhadap kreativitas visual masing-masing mahasiwa.

\section{Hasil dan Pembahasan}

Sesuai instruksi soal tugas yang diberikan, mahasiswa diminta merancang desain poster iklan tentang makanan atau minuman lokal yang ada di Sulawesi selatan khususnya di Kota Makassar. Tugas ini mewajibkan kepada mahasiswa agar menggunakan visual secara bebas sebagai bagian utama dari poster yang dibuat. Hasil desain poster kemudian dipilih sebanyak 36 lembar untuk diteliti secara lebih mendalam. Poster yang dikaji dalam penelitian ini berjumlah 36 lembar, terdiri dari kelas A sebanyak 20 lembar dan kelas B sebanyak 16 lembar. Pada umumnya hampir sleuruh poster menggunakan visual produk sebagai ilustrasi untuk menyampaikan pesan, selain pada identitas yang dituliskan dengan berbagai karakter tipografi.

Secara umum hasil penelitian dapat dikategorikan berdasarkan jenis kuliner lokal yang diangkat adalah: 1) Sarabba, Markisa dan Kopi terdiri dari 5 poster; 2) Pisang terdiri dari 6 poster; 3) Kue kering dan basah terdiri dari 11 poster; 4) coto dan konro sebanyak 8 poster; 5) Jalangkote, songkolo dan bebek sebanyak 6 psoter. Berdasarkan kategorisasi tersebut terlihat bahwa jenis kuliner yang banyak dipilih untuk dibuatkan desain iklan posternya adalah jenis kue kering dan basah sebanyak 11 poster, hal ini disebabkan banyaknya pilihan dan jenis kue tradisional yang dapat diriset dan data visualnya lebih mudah diperoleh. Terbanyak kedua adalah coto 
dan konro sebanyak 8 poster dengan kemasan visual yang hampir sama yaitu suguhan coto dalam mangkuk tanpa model. Pisang dengan berbagai olahan terdiri dari 6 poster. 6 Poster lainnya mengangkat jalangkote, songkolo dan bebek.

Poster yang mengangkat jenis kue basah dan kue kering menggunakan visual kue dengan kemasannya sebagai visual utama pada umumnya tidak menggunakan model sebagai visual tambahan atau penunjang. Jenis kuliner coto dan konro yang disajikan dalam 8 poster pada umumnya menggunakan visual coto dan konro dalam mangkuk yang diharapkan dapat menggugah selera pembeli kedelapan poster ini juga menggunakan visual coto dan konro dalam kemasan wadah piring siap saji, beberapa diantaranya dilengkapi dengan hidangan bumbu dan diletakkan di atas meja tanpa ada model yang sedang menyantap coto. Poster yang mengangkat pisang dengan berbgaia olahan seperti pisang epe, pisang ijo dan pisang coklat menggunakan hidangan pisang siap saji tanpa menggunakan model, demikian juga dengan poster yang mengangkat jalangkote, songkolok, dan bebek umumnya produk makanan yang ditata dan di kemas siap santap dan tidak menggunakan model atau visual penunjang yang memadai.

Setelah menyajikan ulasan visual dari lima kategori poster yang mengangkat makanan dan minuman lokal maka terlihat bahwa jenis visual yang banyak digunakan adalah jenis visual produk yang ditata secara menarik lalu difoto dan digunakan sebagai gambar visual pada poster. Kecenderungan untuk menggunakan visual produk berupa hasil fotografi sebagai visual utama iklan media poster memberi kesan lebih sederhana, dan lebih terkesan sebagai kemasan produk daripada iklan kreatif.

Secara estetik, pada umumnya seluruh poster sudah memenuhi aspek keindahan khususnya aspek visual yang digunakan, walaupun masih terbatas pada visual produk hasil fotografi, namun prinsip penataan dan prinsip-prinsip desain telah diterapkan dengan baik sehingga fungsi poster sebagai pemberi informasi terhadap pelanggang dapat diwujudkan, tentu saja visual dalam poster itu juga telah memiliki hubungan dengan bodycopy dan headline yang digunakan.

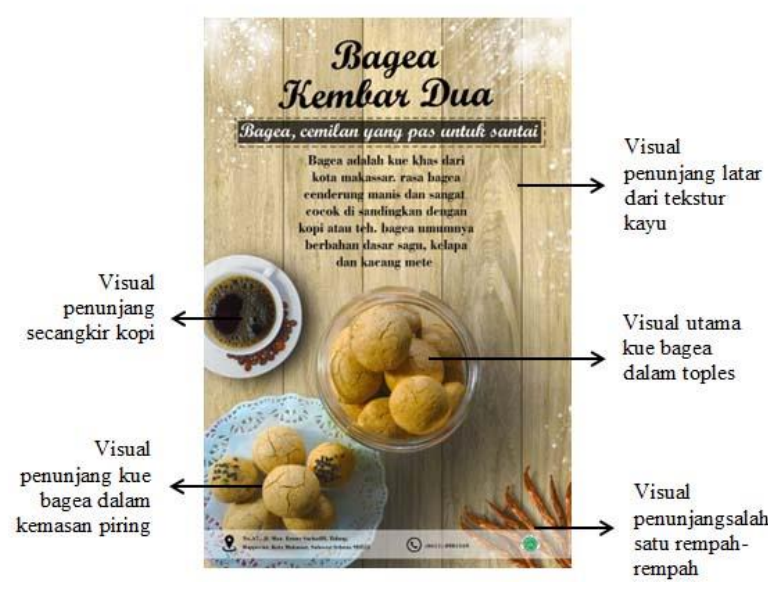

Gambar 1. Poster iklan kue bagea dengan visual produk 
Irfan, Jalil, Satriadi, Kreativitas Visual Pada Desain Poster Iklan Komersial Karya Mahasiswa. Hlm 28-35

Jika melihat kembali fungsi gambar atau visual dalam desain poster iklan diantaranya adalah; dapat membangkitkan keinginan yang besar, untuk mengekspresikan perasaan, untuk mengkomunikasikan gagasan, menerangkan hubungan yang kompleks, menjadi obyek estetika, mengajak untuk berimajinasi, dan untuk menjelaskan suatu informasi yang menyertainya, maka secara umum fungsi visual telah tercapai, namun lebih jauh dari itu visual belum mampu menerangkan hubungan yang kompleks serta belum mampu mengajak berimajinasi. Oleh sebab itu, ditinjau dari aspek kreativitas dan kaitannya dengan ajakan berimajinasi bagi pelanggang, visual yang digunakan belum menawarkan kreativitas yang mumpuni, sebab masih membatasi diri pada visual produk saja tanpa melibatkan visual penunjang seperti model yang lebih dapat membangkitkan keinginan karena adanya figur yang dilihat sebagai sebuah testimoni yang menarik. Di sisi lain, hal tersebut boleh jadi karena instruksi tugas poster ini belum menekankan pada pentingnya visual model sebagai penunjang dalam iklan poster.

Setelah menyajikan ulasan visual dari lima kategori poster yang mengangkat makanan dan minuman lokal maka terlihat bahwa jenis visual yang banyak digunakan adalah jenis visual produk yang ditata secara menarik lalu difoto dan digunakan sebagai gambar visual pada poster. Kecenderungan untuk menggunakan visual produk berupa hasil fotografi sebagai visual utama iklan media poster memberi kesan lebih sederhana, dan lebih terkesan sebagai kemasan produk daripada iklan kreatif.

Secara estetik, pada umumnya seluruh poster sudah memenuhi aspek keindahan khususnya aspek visual yang digunakan, walaupun masih terbatas pada visual produk hasil fotografi, namun prinsip penataan dan prinsip-prinsip desain telah diterapkan dengan baik sehingga fungsi poster sebagai pemberi informasi terhadap pelanggang dapat diwujudkan, tentu saja visual dalam poster itu juga telah memiliki hubungan dengan bodycopy dan headline yang digunakan.

Jika melihat kembali fungsi gambar atau visual dalam desain poster iklan diantaranya adalah; dapat membangkitkan keinginan yang besar, untuk mengekspresikan perasaan, untuk mengkomunikasikan gagasan, menerangkan hubungan yang kompleks, menjadi obyek estetika, mengajak untuk berimajinasi, dan untuk menjelaskan suatu informasi yang menyertainya, maka secara umum fungsi visual telah tercapai, namun lebih jauh dari itu visual belum mampu menerangkan hubungan yang kompleks 
serta belum mampu mengajak berimajinasi. Oleh sebab itu, ditinjau dari aspek kreativitas dan kaitannya dengan ajakan berimajinasi bagi pelanggang, visual yang digunakan belum menawarkan kreativitas yang mumpuni, sebab masih membatasi diri pada visual produk saja tanpa melibatkan visual penunjang seperti model yang lebih dapat membangkitkan keinginan karena adanya figur yang dilihat sebagai sebuah testimoni yang menarik. Di sisi lain, hal tersebut boleh jadi karena instruksi tugas poster ini belum menekankan pada pentingnya visual model sebagai penunjang dalam iklan poster.

\section{Kesimpulan}

Setelah menyajikan ulasan visual dari lima kategori poster yang mengangkat makanan dan minuman lokal maka terlihat bahwa jenis visual yang banyak digunakan adalah jenis visual produk yang ditata secara menarik lalu difoto dan digunakan sebagai gambar visual pada poster. Kecenderungan untuk menggunakan visual produk berupa hasil fotografi sebagai visual utama iklan media poster memberi kesan lebih sederhana, dan lebih terkesan sebagai kemasan produk daripada iklan kreatif.

Secara estetik, pada umumnya seluruh poster sudah memenuhi aspek keindahan khususnya aspek visual yang digunakan, walaupun masih terbatas pada visual produk hasil fotografi, namun prinsip penataan dan prinsip-prinsip desain telah diterapkan dengan baik sehingga fungsi poster sebagai pemberi informasi terhadap pelanggang dapat diwujudkan, tentu saja visual dalam poster itu juga telah memiliki hubungan dengan bodycopy dan headline yang digunakan.

Jika melihat kembali fungsi gambar atau visual dalam desain poster iklan diantaranya adalah; dapat membangkitkan keinginan yang besar, untuk mengekspresikan perasaan, untuk mengkomunikasikan gagasan, menerangkan hubungan yang kompleks, menjadi obyek estetika, mengajak untuk berimajinasi, dan untuk menjelaskan suatu informasi yang menyertainya, maka secara umum fungsi visual telah tercapai, namun lebih jauh dari itu visual belum mampu menerangkan hubungan yang kompleks serta belum mampu mengajak berimajinasi. Oleh sebab itu, ditinjau dari aspek kreativitas dan kaitannya dengan ajakan berimajinasi bagi pelanggang, visual yang digunakan belum menawarkan kreativitas yang mumpuni, sebab masih membatasi diri pada visual produk saja tanpa melibatkan visual penunjang seperti model yang lebih dapat membangkitkan keinginan karena adanya figur yang dilihat sebagai sebuah testimoni yang menarik. Di sisi lain, hal tersebut boleh jadi karena instruksi tugas 
Irfan, Jalil, Satriadi, Kreativitas Visual Pada Desain Poster Iklan Komersial Karya Mahasiswa. Hlm 28-35

poster ini belum menekankan pada

pentingnya visual model sebagai penunjang

dalam iklan poster.

\section{DAFTAR PUSTAKA}

Alwi, Hasan, et al., Kamus Besar Bahasa Indonesia, Jakarta: Balai Pustaka, 2007.

Ali, Matius, Estetika, Pengantar Filsafat Seni, Jakarta: Sanggar Luxor, 2011.

Kusmiati, Artini. (et.al)., Disain Komunikasi Visual. Jakarta. Djambatan, 1999.

Marianto, M Dwi, Art \& Levitation, Seni dalam Cakrawala, Yogyakarta, Penerbit Pohon Cahaya, 2015.

Masri, Andry, Strategi Visual Bermain Dengan Formalistik dan Semiotik Untuk Menghasilkan Kualitas Visual Dalam Desain, Yogyakarta: Jalasutra, 2010.

Miles, M.B. dan Huberman. Analisis Data Kualitatif, (Penerjemah: Tjetjep Rohendi Rohidi), Jakarta: (UIPRESS), 1992.

Parker, DeWitt H. The Principles of Aesthetics, Second Edition, New York: Appleton Century Crofts Inc. 1964.

Widagdo. Desain dan Kebudayaan. Bandung: Penerbit ITB. 2005.

Sachari, Agus. Paradigma Desain Indonesia, Jakarta: CV. Rajawali, 1986.

Sachari, Agus, Yan Yan S. Desain dan Dunia Kesenirupaan Indonesia dalam Wacana Transformasi Budaya, Bandung: Penerbit ITB, 2001.

Sutopo, H.B., Metodoloi Penelitian Kualitatif; Dasar Teori dan Terapannya dalam Penelitian, Surakarta, Sebelas Maret University Press, 2002. 
Jurnal Pakarena, Volume 4 Nomor 1, Juni 2019 